\title{
SUBJETIVIDAD, ESPECTRO Y VIOLENCIA EN ARTE DE MORIR DE ÓSCAR HAHN
}

\author{
POR \\ Matías Ayala \\ Universidad de Talca
}

La poesía de Óscar Hahn (Chile, 1938) -en particular Arte de morir (1977)-ha sido reconocida por la crítica como hecha por un poeta culto y gran artesano de la poesía hispanoamericana. Su capacidad para actualizar y sintetizar estilos poéticos diversos -a nivel enunciativo, fonético, léxico, métrico y sintáctico- es notable. ${ }^{1}$ Lihn, respecto a esto, habló del "doblaje mimético de esos materiales" (101), en donde la dicotomía emulación/creación queda disuelta. Sin duda, Hahn logra renovar estas referencias, esto es, traer al presente elementos del pasado manteniendo la distancia de su historicidad.

En Arte de morir los distintos registros intertextuales conllevan distintos sujetos enunciativos y personajes que impiden las supuestas certezas del sujeto lírico. Adiferencia de lo que ocurre en la tradición lírica, en la obra de Hahn no se encuentra un "interior" subjetivo plausible, ya sea biográfico o ficcionalizado en el texto; ni menos, con cierta consistencia de sus coordenadas espaciales y temporales. La intertextualidad en Hahn llega a deshacer lo que se entiende por "creación original", incluso en un nivel práctico. ${ }^{2}$ La única sección de Arte de morir en donde un sujeto se hace plausible es en los poemas en los que se utiliza un registro oral -a veces excedido por la violencia- pero ellos no son lo suficiente en cantidad como para cohesionar el volumen.

Por todo esto, la figura del sujeto es problemática en la obra de Hahn. Lejos de presentar una identificación del sujeto enunciativo de sus poemas (o hablantes) con

\footnotetext{
1 Las fuentes y estilos que Hahn reescribe -sin caer en la copia inconsciente o la irónica parodia- son múltiples: La Biblia (Apocalipsis), la Edad Media (Villon, Danzas de muerte, Cancioneros populares), la poesía popular chilena (y sus finales de mundo), el Renacimiento (Garcilaso de la Vega, San Juan de la Cruz), el Barroco (Góngora y Quevedo), el simbolismo (Rimbaud), la vanguardia (Apollinaire, Huidobro, Eliot) y la literatura fantástica.

2 Esto resulta patente en la suerte que ha corrido el volumen de Hahn Flor de enamorados, el cual es una reescritura -una edición y actualización- de un cancionero medieval del siglo xv. La figura del "corrector" no ha sido del agrado de los editores: ha sido marginalizado y acortado en las sucesivas antologías de Hahn, ya que no califica completamente como una "creación original". Flor de enamorados no se encuentra en Tratado de sortilegios, Antología retroactiva ni en Obras selectas. Sí, en cambio, en Antología virtual y en Obra poética, donde se ubica al final del texto como "Apéndice".
} 
un yo biográfico o autoral (o sujeto lírico) que les dé un sentido, hay un constante descentramiento en su obra. Entre las intertextualidades y los registros orales, la mirada y el sujeto fantasmal, las narrativas fantásticas y psicoanalíticas de Hahn, el sujeto textual -por lo general, una de las construcciones más importantes de los discursos poéticos- es particularmente elusivo.

En las páginas siguientes se hará una lectura de las relaciones entre subjetividad y violencia en Arte de morir. En una primera instancia, una fuerte despersonalización predomina en los poemas que le dieron fama internacional. En particular, los sobrevivientes o testigos de sus textos apocalípticos toman cuerpo textual a través de la indeterminada figura del fantasma o el espectro. Asimismo, en aquellos poemas que versan sobre la violencia política de la dictadura militar de A. Pinochet, el sujeto espectral prosigue como articulador del texto, aunque la violencia se enmarca en juegos intertextuales, epígrafes y marcadores temporales. Lo que persiste en ambas estrategias textuales, como se verá, es evitar una nominación referencial de la política a través de un sujeto estable.

\section{VIOLENCIA, ESPECTRO Y POST-APOCALIPSIS}

Las relaciones entre violencia y sujeto han sido persistentes en la obra de Óscar Hahn. La violencia puede entenderse, en primera instancia, como una fuerza física no autorizada o una amenaza de ella (Williams 278), o como articulada por un carácter instrumental (Arendt 63); esto es lo que Žižek categoriza más recientemente como "violencia subjetiva": asaltos, asesinatos, terror, guerras, etc. en las que puede identificarse un agente (1). Más interesante, es pensarla en un nivel "sistémico" y su función legitimadora en relación a la ley y al sujeto. Benjamin en "Para una crítica de la violencia" propuso que la Ley no tiene legitimidad más allá de la violencia (o poder, los dos sentidos de Gewalt), es decir, que la violencia misma es la fundadora de ley (114). De esta manera, el individuo deviene "sujeto" del lenguaje, la ley y la sociedad que codifican y administran la violencia (Balibar 138). Así, se pueden entender el "orden simbólico" de Lacan, los “Aparatos Ideológicos de Estado" de Althusser, los "procesos de subjetivación" que producen el poder y el saber de las instituciones para Foucault Si bien estos autores sostienen diferencias en sus articulaciones teóricas del sujeto y el poder, todos coinciden en que sólo hay sujeto en relación a instituciones de poder.

Paradójicamente -en el otro extremo, teórico y conceptual, el abierto por Freudla experiencia misma de la violencia es la causa de un "trastorno" subjetivo. Esto es lo que Freud entiende como el trauma: la súbita y violenta intromisión del exceso físico y psíquico, que mediado y potenciado por elementos técnicos, es incapaz de ser administrado por el sujeto. En "Más allá del principio del placer" (1920) Freud propuso comprender el trauma (o "neurosis traumática") con una temporalidad dilatada en dos tiempos. Primero, la exposición de un sujeto a un accidente o evento donde la vida estuvo en peligro, el cual no es experimentado ni simbolizado de manera apropiada debido a la violencia inesperada y rapidez: "el centro de gravedad de la causación parece situarse en el factor de la sorpresa, en el terror [Scherck]" (12). El evento, entonces, atraviesa el consciente y es registrado en el inconsciente donde hiere. Hartman lo propone así: "Something 'falls' into the psyche, or causes it to 'split.' There is an original catastrophe whereby/in which an experience that is not experienced (and so, apparently, not "real") has an exceptional presence-is inscribed with a force proportional to the mediations punctured or evaded" ("Traumatic Knowledge" 537).

En el segundo momento del trauma los eventos registrados inconscientemente se manifiestan a través de sueños y acciones insistentes en la compulsión de la repetición: "La vida onírica de la neurosis traumática muestra este carácter: reconduce al enfermo, una y otra vez, a la situación de su accidente, de la cual despierta con renovado terror" (13). Si los acontecimientos que cruzan al inconsciente hieren al sujeto aunque sin aparente dolor, la vuelta, la revancha de ellos en la consciencia del sujeto es la voz, que a través de la herida es producida y amplificada. Estos acontecimientos necesitan de esa compulsión de la repetición que ellos mismos produjeron para poder emerger: "Trauma $[\ldots]$ it is always the story of a wound that cries out, that adresses us in the attempt to tell us of a reality or truth that is not otherwise available" (Caruth 4). Este retorno de lo reprimido es el elemento perturbador de la voz del trauma, lo que desarma la certitud de la identidad subjetiva al exponer al inconsciente en el consciente como huella de la violencia. El trauma así pone "en juicio", deconstruye y desestabiliza al sujeto.

Esta ubicación de la violencia en estos dos extremos del inconsciente-el de la teoría política y el del psicoanálisis- es lo que la vuelve un objeto tan elusivo en términos conceptuales. Hablar de sus manifestaciones desde el discurso de la política, la historia, la sociología y el urbanismo es mucho más fácil. La certeza de su propia institucionalidad les permite una representación distanciada para así administrar su visibilidad. En término literarios, en cambio, la pregunta es mucho más compleja porque la cuestión misma de la representación y del sujeto está cuestionada. El texto literario debe hacerse cargo, consciente o inconscientemente, de una serie de problemas ineludibles: qué y cómo se representa, cómo se articula la relación con los demás discursos que hablan de la violencia (la historia, la política y otros textos literarios, por ejemplo); cómo se administra el dramatismo y lo traumático, la empatía y el placer de la lectura, o al contrario, cómo se lidia con el distanciamiento crítico y una reflexión ética. En definitiva, el texto literario propone una forma de representación mucho menos distanciada que las "ciencias" humanas y sociales (las que descansan en un enunciación neutra) sino que además debe crear un sujeto textual desde donde llevar esta figuración a cabo.

En el caso de Hahn, el sujeto textual que se enfrentará con la violencia -la que también constituye y desarma al sujeto- será el fantasma. El fantasma es el sujeto enunciativo de una serie de sus poemas que le permite despersonalizar y descentrar su 
obra, tal como lo ha notado Giordano (95) para así articular lo traumático y lo colectivo de la experiencia histórica. Si bien, la aparición "oficial" y pública del fantasma fue en Mal de amor (1981) en donde es el personaje que actúa en varias páginas, su presencia en la obra de Hahn rondaba desde antes. En Arte de morir el espectro es el sujeto que detenta la mirada en los poemas apocalípticos. Por ejemplo en "Ciudad en llamas":

$$
\begin{aligned}
& \text { Entrando en la ciudad por alta mar } \\
& \text { la grande bestia vi: su rojo ser } \\
& \text { Entré por alta luz por alto amor } \\
& \text { entréme y encontréme padecer } \\
& \text { Un sol al rojo blanco en mi interior } \\
& \text { crecía y no crecía sin cesar } \\
& \text { y el alma con las hordas del calor } \\
& \text { templóse y contemplóse crepitar } \\
& \text { Ardiendo el más secreto alrededor } \\
& \text { mi cuerpo en llamas vivas vi flotar } \\
& \text { y en medio del silencio y del dolor } \\
& \text { hundióse y confundióse con la sal: } \\
& \text { entrando en la ciudad por alto amor } \\
& \text { entrando en la ciudad por alta mar }
\end{aligned}
$$

De este soneto la crítica ha notado cómo la rima se funde con las semejanzas fónicas de las palabras (paranomasia), las que funcionan como elementos binarios (Palau de Nemes 54) y que los finales agudos tienen algo pesadillesco (Yamal 31). Habría que notar también algunos cambios en el poema. El primer cuarteto muestra la visión exterior de "la grande bestia" (lo que por el título y el contexto nuclear deducimos que es la bomba atómica, aunque bien este podría ser un poema de amor en cual la destrucción e incendio ocupan el lugar del enamoramiento). En el siguiente cuarteto el foco cambia dentro del sujeto (el alma), en donde también el fuego parece quemarlo. Después, hay un nuevo cambio ya que el sujeto se desdobla en alma y cuerpo -es decir, muere- y mira su cuerpo arder y flotar para finalmente fundirse con el mar y terminar repitiendo el inicio. Si sopesamos los cambios subjetivos de este poema, habría que decir que quien enuncia retrospectivamente esta narración es el sujeto después de muerto, es decir, es el mismo espectro del sujeto lírico.

La muerte y la violencia son las fuerzas que pervierten la fijación del sujeto. En el poema "Visión de Hiroshima", probablemente el texto apocalíptico más famoso de Hahn, el registro profético emula el Apocalipsis bíblico de San Juan (aunque también Blake y Neruda). Enmarcado con un epígrafe sánscrito sobre el fin del mundo, la profecía se presenta como el conocimiento absoluto por visión y revelación (Santí 15), lo que consiste en una acumulación de imágenes de destrucción. ISSN 0034-9631 (Impreso) ISSN 2154-4794 (Electrónico)
El poema está dividido en tres estrofas: dos muy breves al comienzo y al final, y una extensa al medio de treinta y seis versos. Como notó Nick Hill, la primera estrofa funciona como una advertencia hacia los hombres, como un juicio y moraleja al poema (44-45). Esta advertencia hay que tomarla como una posición literaria clara respecto a la amenaza nuclear que Hahn adopta: "Ojo con el ojo numeroso de la bomba / que se desata bajo el hongo vivo. / Con el fulgor del Hombre no vidente, ojo y ojo" (Arte de morir, 1 era ed, 57). La posterior enumeración que se desencadena muestra la ambivalencia de la psicología profética: por una parte simpatiza con el poder de la visión destructiva que logra captar, y por la otra, experimenta un horror ante lo representado (Hartman "Poetics of Prophecy”165). Quizás es por esta duplicidad que Hahn comienza el poema con la moraleja, para evitar así la confusión desde un inicio. Prosigue el poema:

\author{
Los ancianos huían decapitados por el fuego, \\ encallaban los ángeles en cuernos sulfúricos \\ decapitados por el fuego, \\ se varaban las vírgenes de aureola radioactiva \\ decapitadas por el fuego. \\ Todos los niños emigraban decapitados por el cielo. \\ $[\ldots]$ \\ Vimos las cúpulas fosforecer, los ríos \\ anaranjados pastar, los puentes preñados \\ parir en medio del silencio. \\ El color estridente desgarraba \\ el corazón de sus propios objetos: \\ el rojo sangre, el rosado leucemia, \\ el lacre llaga, enloquecidos por la fisión. \\ El aceite nos arrancaba los dedos de los pies, \\ las sillas golpeaban las ventanas \\ flotando en marejadas de ojos, \\ los edificios licuados se veían chorrear \\ por troncos de árboles sin cabeza, \\ y entre las vías lácteas y las cáscaras, \\ soles o cerdos luminosos \\ chapotear en las charcas celestes [...]. (58-59)
}

Este poema-articulado a partir de verbos pretéritos-suma imágenes de destrucción y transmutación (incendio, licuefacción, cambios violentos), algunas fantásticas y otras aparentemente testimoniales y colectivas. Uno de los logros del poema es combinar la distancia y el patetismo con las imágenes de destrucción. Nick Hill ha sugerido que "el tono oracular de la voz profética y su autoridad impersonal producen un desajuste con la terribilidad de la descripción del infierno que repentinamente cae del cielo" (Hill 45). Tal como en otros textos de Hahn que suelen ser considerados fantásticos, la

Revista Iberoamericana, Vol. LXXIX, Núms. 244-245, Julio-Diciembre 2013, 651-664 ISSN 0034-9631 (Impreso) ISSN 2154-4794 (Electrónico) 
narrativa está dislocada por cambios espaciales y temporales y al mismo tiempo el sujeto muestra una persistente transmutación. En "Visión de Hiroshima" el saber absoluto de fin del mundo, percibido en términos visuales, va acompañado de la impersonalidad perturbadora. La relación entre ambos ha sido enlazada por Derrida:

No se sabe muy bien quién presta su voz y su tono al otro en el Apocalipsis, no se sabe muy bien quién dirige el qué a quién. Pero por un trastocamiento catastrófico, aquí más necesario que nunca, se puede igualmente pensar esto: puesto que no se sabe ya quién habla o quién escribe, el texto se vuelve apocalíptico. (Sobre un tono apocaliptico 61-2)

Debido a la ausencia de un sujeto que pueda ser determinado, sólo se puede tener el punto de vista apocalíptico desde un afuera (ya sea del sujeto, la historia o el mundo).

Y el poema termina: "Por los peldaños radioactivos suben los pasos, / suben los peces quebrados por el aire fúnebre. / ¿Y qué haremos con tanta ceniza?” (59). Quien enuncia esto, entonces, es el fantasma o el espectro, es una voz sin alma ni cuerpo que habla desde un más allá (Derrida, Espectros de Marx 20-21), desde un momento postapocalíptico. James Berger ha trabajado esta figura del post-apocalipsis al notar que el fin sobre el cual el texto literario habla nunca es el fin del mundo mismo, ni del mundo representado ni tampoco es el fin texto (6). Siempre hay algo después del fin, el lugar desde donde el texto se enuncia: este es el post-apocalipsis, ya que se acaba el mundo pero el escritor sigue escribiendo.

En el caso de este poema, el sujeto de enunciación es el fantasma, una presencia deshecha o a medio deshacer, una mirada y una voz imposible que se encuentra del lado del objeto. Desde ahí es que Hahn lleva a cabo su reflexión final, mucho más efectiva que la reflexión moralizante y juzgadora del inicio del poema, ya que no da recomendaciones sentenciosas al futuro desde la cómoda posición de la distancia intelectual, sino que desde un futuro posible nos pregunta virtualmente (a los lectores) por la acción a seguir después de la destrucción total.

Estos poemas apocalípticos de Óscar Hahn -escritos la mayoría de ellos durante los años sesenta- son una manera de dar forma a un antagonismo, de hacerse cargo de la Guerra Fría con sus oposiciones imperiales y diplomáticas, tecnológicas y deportivas, y su catástrofe nuclear. Kermode, en El sentido de un final, propone que en momentos de transición, las imágenes apocalípticas dan un sentido al pasado, el presente y el futuro en forma de crisis (95). Es más, la misma idea de modernidad como un momento de perpetua transición, en donde se pierde la relación con el pasado (102), es un ejemplo de ello. Frente a eso, estos poemas apocalípticos anticipan y apuran el fin del tiempo, tanto con deseo como con miedo, sostiene Hartman ("The Poetics of Prophecy" 167). Si bien lo apocalíptico es una relación anticipatoria e intensificada del tiempo, por lo general la enunciación de estos poemas de Hahn se lleva a cabo desde un perpetuo presente de la visión fantasmal y desde un espacio post-apocalíptico. Un presente

Revista Iberoamericana, Vol. LXXIX, Núms. 244-245, Julio-Diciembre 2013, 651-664 ISSN 0034-9631 (Impreso) ISSN 2154-4794 (Electrónico) en donde la destrucción sucede y ya sucedió. Este acontecimiento presente crea una suerte de "agujero en el tiempo", de "trauma" en la textura temporal que provoca una fuerte conciencia del tiempo ("Poetics of Prophecy" 171). Berger también elabora en torno a esta confusión temporal del apocalipsis ya que en estos textos se implica el presente actual, se prefigura el momento de destrucción y lo que viene después (6). Esta temporalidad no-lineal del post-apocalipsis es similar a la del trauma en donde el pasado se inscribe en el presente.

No obstante, hacia el futuro es imposible saber si Hahn prosigue el imaginario tradicional apocalíptico según el cual debería haber regeneración futura -es decir, si esta violencia y destrucción logrará crear una nueva ley- o si, por el contrario, este final solo será la catástrofe última. Martin Jay -siguiendo a Klaus Sherpe- ha propuesto que las narrativas apocalípticas del modernismo proponen un epílogo redentor, mientras que el postmodernismo, en cambio, solo enfatiza la destrucción desdramatizando y difiriendo el fin (Jay 173-4). En el caso de Hahn, hay otro momento de incertidumbre; ignoramos si propone o no una posible regeneración. A veces, la historia se presenta como circular y desdramatiza el fin al continuar la historia a través del espectro radiactivo. ${ }^{3}$

\section{SUJETO Lírico y POLÍTICAS TEXTUALES}

Hasta no hace mucho tiempo frente a la pregunta “¿quién es ese que habla en un poema?" la respuesta tradicional era "el poeta". Esta postura, de filiación romántica, supone el texto poético como expresión del autor y, de esta manera, entiende la poesía como dotada de función autobiográfica. Solidaria del sujeto aislado y autónomo de la filosofía moderna y de la teoría política liberal, el romanticismo hizo de esta una física y una metafísica, ya que la subjetividad privilegiada del poeta y que es completamente transparente a sí mismo, deviene la fuente de la poesía.

La ola estructuralista de postguerra atacó esta noción de forma radical y efectiva. Es conocida la distinción de E. Benveniste entre "sujeto del enunciado" (el yo gramatical de la frase) y el "sujeto de la enunciación" (el yo que emite el discurso). Si bien los pronombres y deícticos (aquí, ahora) son las marcas del sujeto de enunciación, Benveniste enfatiza la separación entre ambos (83). Este espacio le permitió a Barthes proponer que la literatura no es expresión del escritor sino la dispersión de él en texto, por lo tanto, el autor no da el sentido del texto sino el lector (70-71). Foucault, frente al destronamiento del escritor propuso la "función autor": rasgos institucionales (legales, culturales) que

\footnotetext{
En "Adán recuerda la fallida destrucción del árbol de la ciencia" de Estrella fijas en un cielo blanco de Hahn, la pareja primordial, que desea quemar el paraíso, es castigada y prosigue una fantasmal vida radiactiva. O en "Adán postrero" de Versos robados, el sujeto que sobrevive el debacle nuclear es un Adán post-humano, a la manera huidobriana, que aspira a regenerar la especie. El poema comienza: "Sentado en un montón de escombros / espero a la mutante que será mi mujer" (29).

Revista Iberoamericana, Vol. LXXIX, Núms. 244-245, Julio-Diciembre 2013, 651-664 \begin{tabular}{ll}
\hline ISSN 0034-9631 (Impreso) & ISSN 2154-4794 (Electrónico)
\end{tabular}
} 
ciertos textos adquieren en su circulación social (339). Benveniste, Barthes y Foucault reconocen que entre el escritor y los hablantes ficticios hay un hiato imposible de cruzar. No obstante, si bien ellos atacan a la función expresiva al mismo tiempo dejan el problema sin resolver: ¿qué tipo de sujeto es ese creado por el texto? ¿Un puro sujeto textual? ¿Y cómo se relaciona este con el autor y el escritor?

Habría que llamar enunciación lírica al "sujeto poético", "el hablante" o "yo lírico" del poema y/o de un libro, es decir, el lugar enunciativo en donde la multiplicidad de hablantes de un texto poético toma una cierta unidad. El sujeto lírico -sostiene Stierle en un seminal ensayo- transgrede la coherencia del discurso al evitar la linealidad de la narrativa y al hacer simultáneos contextos diferentes (433). De esta forma, en un poema se puede partir como una meditación íntima o aparentemente biográfica (dotado de coordenadas corporales, temporales y espaciales determinadas) y, pasar en el próximo párrafo a un escena descontextualizada y despersonalizada, en un registro universal y abstracto (la voz de todo y todo). Esto vuelve al sujeto lírico a un sujeto de identidad problemática, que busca su propia identidad y que se articula líricamente en esa búsqueda (436).

De esta manera, frente a la tradicional oposición de autobiografía y ficción, Rabaté propone que el sujeto lírico deshace esa dicotomía. Este sujeto lírico no es autobiográfico sino un horizonte deseado de subjetividad (Rabaté 67); y si bien se enmarca en un cuadro ficticio o figurativo al mismo tiempo lo pone en duda. En la poesía lírica, el sujeto se mueve entre un sujeto autobiográfico y su ficcionalización, "en proceso" de constituirse y deconstruirse a sí mismo. Es permanente la inestabilidad ya que la suma de posturas enunciativas desbordan todo sujeto y ya que excede el control del poeta (68). El motivo recuerda a Paul de Man cuando propone que es imposible determinar los límites entre autobiografía y ficción, entre referencia y figuración (921).

El fantasma en la obra de Hahn -a través de la cual el sujeto lírico se desdobla y transfigura algo o a alguien (Cumpiano 27)- toma este lugar indeterminación subjetiva. Como se mencionó, la figura del fantasma se hace visible en la poesía de Hahn en Mal de amor (1981). ${ }^{4}$ Ahí, en la escenificación del duelo, el sujeto se transfigura en fantasma para ligarse fantásticamente al objeto perdido: se convierte en sábana, funda de la almohada, toalla o camisa. El fantasma, materialización de la negatividad del (y en) el sujeto, es la figuración de una ausencia o carencia que lo descentra y descoloca, de ese doble amenazador que se encuentra tanto dentro como fuera de él, lo que puede

\footnotetext{
En la primera edición de Mal de amor están "Nacimiento del fantasma", "Fantasma en forma de funda", "Fantasma en forma de camisa", "Sábana de arriba", "Pequeños fantasmas" y "En la vía pública", Después en Apariciones profanas aparece "Palabras de un fantasma anterior a su nacimiento", "Fantasma en forma de toalla", "Los fantasmas de Lisboa". No obstante, las apariciones fantasmales en la obra de
}

ser causado por la amada o el deseo, el inconsciente o la mirada ajena, la muerte o la violencia.

Esta despersonalización y descentramiento del sujeto se asocia, en otro nivel, con la resistencia de Óscar Hahn para tomar una abierta posición política en su escritura de los años setenta y ochenta; es decir, su denegación de la función testimonial y la expresión subjetiva en su poesía. Por el contrario, en su obra los requerimientos políticos y éticos son desplazados a asuntos textuales descentrando la supuesta unidad del sujeto lírico. Por una parte, una gran cantidad de referencias a la relación entre el poeta y la política ocupan un lugar "extratextual" como entrevistas y textos en prosa. Por ejemplo, en una entrevista dijo que "La muerte tiene un diente de oro" fue escrito después de estar preso en 1973 y que "refleja, sublimadamente, una situación difícil" (Piña 168) o que "Fragmentos de Heráclito al estrellarse contra el cielo" es "en el fondo un poema sobre el exilio" (Piña 170). Al leerlos sin ese aviso es prácticamente imposible adivinarlo. O también en 1981 publicó en una revista de exiliados chilenos "Testimonio de un poeta" en donde da cuenta de su encierro en 1973 durante diez días en Arica como forma de eximir esta circunstancia de su poesía.

Toda esta información testimonial y política se encuentra fuera del texto poético, como si hubiera una incompatibilidad entre ambas. Por otra parte, ya desde los años sesenta Hahn utiliza epígrafes y marcadores de eventos políticos e históricos (lo que G. Genette llamó elementos "paratextuales") que guían la lectura y la interpretación desde la periferia o umbral del texto. Es mediante este recurso marginal desde donde se apunta a la referencialidad política, la que suele ser -incluso hoy- predominante en la fijación del sentido de un texto. ${ }^{6}$ En definitiva, mediante recursos intertextuales, extratextuales y paratextuales, Hahn evita la función testimonial en su poesía, ya que hacerlo implica un intento de estabilizar un sujeto y centrarlo en la referencialidad de los hechos y la expresión subjetiva.

\footnotetext{
Publicado en Literatura y chilena, Creación y crítica, 16 Abril/junio 1981 (30-1), después fue reproducido

en la compilación ¿Qué hacía yo el 11 de septiembre? (Santiago: Lom, 1997).
Campos observó que en el soneto "Sangre y nieve" de Agua final (Lima, 1967) lleva como epígrafe "Sampos observó que en el soneto "Sangre y nieve" de Agua final (Lima, 1967) lleva como epígrafe chilena de Agua final (también del '67), el poema queda enmarcado como "Batalla de Stalingrado", lo que facilita el reconocimiento del evento histórico. Diez años después, este poema cambiaría de nombre al preciosista verso de Góngora "O púrpura nevada o nieve roja" en Arte de morir (1977) y desaparece la alusión a la defensa soviética de los nazis, ya sea porque la mención a "Stalingrado" no sería bien vista en el Chile dictatorial de los años setenta, o porque tampoco sería bien recibido en los EE UU., en donde Hahn comenź a vivir desde 1974 (o por algun otra raźn). Esta supresión convierte al poema en una reflexión la el agua, más que en un pocna politico. Alora bien, una vez ten suer Fría, en Poemas selectos de 2003, y en las sucesivas antología, el poema recupera el epígrafe "Batalla de Stalingrado, 1943" como una suerte de enclave histórico que el poema puede mantener.
}

Revista Iberoamericana, Vol. LXXIX, Núms. 244-245, Julio-Diciembre 2013, 651-664 ISSN 0034-9631 (Impreso) ISSN 2154-4794 (Electrónico)
Revista Iberoamericana, Vol. LXXIX, Núms. 244-245, Julio-Diciembre 2013, 651-664 ISSN 0034-9631 (Impreso) ISSN 2154-4794 (Electrónico) 
"Un ahogado pensativo a veces desciende" - publicado en la segunda edición de Arte de morir, 1979- ha de ser uno de los primeros y más directos poemas políticos de Óscar Hahn escrito durante esa época. Con un epígrafe de "El barco ebrio" de Rimbaud "flottaison blême et ravie" ("flotación lívida y arrebatada") "Un ahogado pensativo a veces desciende" reconoce su inspiración intertextual. ${ }^{7}$ Lo transcribo completo:

\section{hay un muerto flotando en este río \\ y hay otro muerto más flotando aquí: \\ esta es la hora en que los pobres símbolos \\ huyen despavoridos: mira el agua}

hay otro muerto más flotando aquí

alguien corre gritando un nombre en llamas

que sube a tientas y aletea y cae

dando vueltas e ilumina la noche

hay otro muerto más flotando aquí

caudaloso de cuerpos pasa el río: almas amoratadas hasta el hueso vituperadas hasta el desperdicio

hay otro muerto más flotando aquí

duerme flotación pálida: desciende a descansar: la luna jorobada

llena el aire de plata leporina

tomados de la mano van los muertos

caminando en silencio sobre el agua (Arte de morir, 2da ed. 93-4)

Este poema logra su efectividad en el contraste entre el movimiento de los cuerpos en el río y el detenimiento del sujeto que los reconoce, los apunta y se sorprende de sumarlos. Los deícticos son particularmente importantes, ya que marcan la presencia de sujeto frente al horror, por lo tanto el poema se propone bajo ese régimen testimonial, aunque curiosamente impersonal y distanciado: "hay otro muerto más flotando aquí". Los

\footnotetext{
El título y el epígrafe se encuentran juntos en la sexta estrofa de "El barco ebrio" de Rimbaud. Ésta es la estrofa: "Y desde entonces, me he bañado en el Poema / del Mar, infundido de astros, y casi lactescente, 1 devorando los azures verdes; por donde, flotación lívida / y arrebatada, un ahogado pensativo a veces desciende" (la traducción es mía).

Revista Iberoamericana, Vol. LXXIX, Núms. 244-245, Julio-Diciembre 2013, 651-664 \begin{tabular}{llll}
\hline ISSN 0034-9631 (Impreso) & ISSN 2154-4794 (Electrónico)
\end{tabular}
}

muertos no tienen rasgos que los distingan entre sí, sólo forman parte de una colección sin principio ni fin. El final, iluminado por la luz de la luna, tan benefactora como mortuoria, redime rápidamente a los muertos y aliviana el conflicto al proponerlos como fantasmas que vuelan sobre el agua hacia el mar (la muerte). El poema, en definitiva, estetiza la muerte de los cuerpos que bajaron por el río Mapocho de Santiago de Chile los días siguientes al 11 de septiembre de 1973. El cierre, eso sí, no pretende ser realista n testimonial, más bien podría entrar en la categoría de "poema fantástico": ver fantasmas o espectros es un motivo clásico de ese género.

Sí habría que preguntarse por el sujeto de la enunciación de este poema: testimonial y distanciado, reiterativo y preciosista, visualmente contrastado pero abstracto, político y espectral, no es claramente una figuración textual del poeta en exilio, el énfasis en los deícticos lo hace imposible. Por otra parte, tampoco podría ser un poema del "intelectual" distanciado que juzga o redime el sufrimiento ajeno debido a la rapidez visual con que los convierte los muertos en fantasmas. El lugar de este sujeto despersonalizado y ubicuo lo ocupa la figura del fantasma. A través de él, Hahn logra combinar la artesanía textual y la representación del momento político y, al mismo tiempo, logra evitar tanto el testimonio como la denuncia del intelectual. El fantasma le permite a Hahn la despersonalización textual, así como la proyección de sus inquietudes políticas, sin ceder en ninguno de los dos campos.

Esta elección, sin embargo, conlleva una disminución fuerte de la carga emotiva y referencial. La lectura política del poema no es patente. Por esto, en la antología Tratado de sortilegios de 1992 -compilación publicada en España de amplia circulación en América Latina- en lugar del epígrafe de Rimbaud se lee "Septiembre de 1973". Posteriormente, cada vez que el poema ha sido reimpreso, la lectura política ha quedado sugerida o "forzada" por ese dato. En "Un ahogado pensativo a veces desciende", el epígrafe temporal es estrictamente un suplemento en términos de J. Derrida: permanece fuera del texto, pero también dentro de él; es algo extraño pero a la vez necesario; deshace la unidad, aunque otorgándole identidad al texto. Lo político del poema consiste es desplazarse como suplemento, lo cual también tiene un cariz fantasmal. Con los cambios de epígrafes obstante, Hahn mantiene la necesidad de dar cuenta de los sucesos políticos e históricos pero esta se aleja del lugar del sujeto lírico referencial y se ubica espacio liminar: en la relaciones entre la texto y los lectores, es decir, en el lugar de autor (Foucault) y la recepción social de su obra.

CIERRE

En la poesía de Óscar Hahn el fantasma es la modalidad en que el sujeto lírico toma cuerpo para poder representar la violencia. La violencia, en tanto que traumática, pone en duda la identidad del sujeto al igual que sujeto lírico se forma en la inestabilidad entre

Revista Iberoamericana, Vol. LXXIX, Núms. 244-245, Julio-Diciembre 2013, 651-664 ISSN 0034-9631 (Impreso) ISSN 2154-4794 (Electrónico) 
autobiografía y ficción. Por esta razón Hahn los entrelaza e utiliza como herramienta poética para aunar testimonio y elaboración poética. Por otra parte, la reticencia de la obra de Hahn en los años setenta y ochenta para hacerse cargo de la violencia política del régimen chileno de modo referencial y su desplazamiento en la textualidad ha de entenderse como una voluntad de tomar distancia del hecho violento, de mostra imposibilidad del testimonio en la poesía. La fuerte conciencia textual le impide a Hahn -que estuvo preso una docena de días, pero que salió al exilio con rapidez- encontrar un lugar certero para articular lo vivido y lo escrito. Por esto, el fantasma o espectro toma el lugar del testigo que es capaz de hablar desde una negatividad, desde en ese "no-lugar de la articulación" entre la vida y el texto (Agamben 137). El sobreviviente en su poesía también es un espectro, ya que él es el que ha pasado realmente por el acontecimiento y podría hablar de él.

Hahn al articular la violencia y la textualidad desplaza al lector la actualización de la política y así hace explotar la linealidad histórica. Ya sea a través a través de la intertextualidad (el poema apocalíptico, el poema simbolista) y de los epígrafes temporales ("Septiembre de 1973") se vuelve incierta la distancia y la valencia política entre el texto original emulado y el de Hahn mismo. Así, Hahn logra hacer una "constelación" o "imagen dialéctica" como querría Walter Benjamin, en donde la yuxtaposición de temporalidades no se resuelve en una unidad mayor, sino que se mantiene la tensión y la no-identidad. Como quería Benjamin, Hahn "desarrolla el arte de citar sin comillas hasta su máxima altura" (La dialéctica en suspenso 114 ) ya que el pasado se hace presente, como el presente se proyecta en el pasado; ambos se iluminan mutuamente a la distancia. La textualidad en Hahn, así, toma un cariz similar al del fantasma -la alusión es el fantasma del texto-, el cual pervierte tiempo, contexto y sentido y se ubica entre el ser y el no ser, entre la vida y la muerte, entre lo actual y lo virtual, lo político y lo literario.

\section{BiBLIOGRAFÍA}

Agamben, Giorgio. Lo que queda de Auschwitz. El archivo y el testigo. Valencia: Pretextos, 2000.

Arendt, Hannah. Sobre la violencia. Madrid: Alianza Editorial, 2005.

Balibar, Étienne. Politics and the Other Scene. London and New York: Verso, 2002.

Barthes, Roland. "La muerte del autor". El susurro del lenguaje. Barcelona: Paidós, 1987. 65-71

Benjamin, Walter. La dialéctica en suspenso. Fragmentos sobre la historia. Pablo Oyarzún, trad. Santiago: Arcis-Lom, 1996

"Para una crítica de la violencia". Ensayos escogidos. H. A. Murena, trad. México: Ediciones Coyoacán, 1999.

Revista Iberoamericana, Vol. LXXIX, Núms. 244-245, Julio-Diciembre 2013, 651-66 ISSN 0034-9631 (Impreso) ISSN 2154-4794 (Electrónico)
Benveniste, Émile. Problemas de lingüistica general II. México: Siglo XXI editores, 1971

Berger, James. After the End: Representations of Post-Apocalypse. Minneapolis: U of Minnesota P, 1999.

Campos, Javier. La joven poesía chilena en el período 1961-1973 (G. Millán, W. Rojas, O. Hahn). Concepción: Lar y ISIL, 1987.

Caruth, Cathy. Unclaimed Experience: Trauma, Narrative, and History. Baltimore and London: John Hopkins UP, 1996.

Cumpiano, Ina. "El otro fantasma en la obra de Óscar Hahn" Asedios a Oscar Hahn. Enrique Lihn y Pedro Lastra, eds. Santiago: Universitaria, 1989. 21-30.

de Man, Paul. “Autobiography as De-facement.” MLN 94/5 (1979): 919-30.

Derrida, Jacques. Espectros de Marx. Madrid: Trotta, 1995.

Sobre un tono apocalíptico adoptado recientemente en filosofía. México: Siglo Veintiuno Editores, 1994

Freud, Sigmund. Más allá del principio del placer en Obras completas XVIII. Buenos Aires: Amorrortu Editores, 1979.

Foucault, Michel. “¿Qué es un autor?” Entre filosofia y literatura. Obras esenciales I. Barcelona: Paidos, 1999. 329-360.

Giordano, Jaime. "Nota sobre Oscar Hahn y la poesía actual". Asedios a Oscar Hahn. Enrique Lihn y Pedro Lastra, eds. Santiago: Universitaria. 1989. 95-8.

Hahn, Óscar. Antología retroactiva. Caracas: Monte Ávila, 1998. Antología virtual. Santiago: FCE, 1995.

Apariciones profanas. Madrid: Hiperión, 2002

Arte de morir. 1era ed. Buenos Aires: Ediciones Hispamérica, 1977.

Arte de morir. 2da ed. Santiago: Editorial Nascimento: 1979.

Flor de enamorados. Santiago: Francisco Zegers editor, 1987.

Mal de amor. 1era ed. Santiago: Ganymedes, 1981.

Obra poética. Santiago: Andrés Bello 2006.

Obras selectas. Santiago: Andrés Bello 2003.

Tratado de sortilegios. Madrid: Hiperión, 1992.

Hartman, Geoffrey H. “On Traumatic Knowledge and Literary Studies.” New Literary History 26 (1995): 537-563.

"The Poetics of Prophecy." The Unremarkable Wordsworth. London: Methuen, 1987. 163-181.

Hill, Nick. "Oscar Hahn o el arte de mirar". Asedios a Oscar Hahn. Enrique Lihn y Pedro Lastra, eds. Santiago: Universitaria, 1989. 39-50.

Jay, Martin. "La imaginación apocalíptica y la incapacidad de elaborar el duelo". Campos de fuerza. Buenos Aires: Paidós, 2003. 167-193.

Kermode, Frank. El sentido de un final. Barcelona: Gedisa, 2001.

Revista Iberoamericana, Vol. LXXIX, Núms. 244-245, Julio-Diciembre 2013, 651-664 
Lihn, Enrique. "Arte del Arte de morir: primera lectura de un libro de Oscar Hahn". Asedios a Oscar Hahn. Enrique Lihn y Pedro Lastra, eds. Santiago: Universitaria, 1989. 99-104.

Palau de Nemes, Graciela. "La 'poesía en movimiento' de Oscar Hahn”. Asedios a Oscar Hahn. Enrique Lihn y Pedro Lastra, eds. Santiago de Chile: Universitaria, 1989. 51-5.

Piña, Juan Andrés. Conversaciones con la poesía chilena. Santiago: Ediciones UDP, 2007.

Rabaté, Dominique. "Énonciation poétique, énonciation lyrique". Figures du sujet lyrique. Dominique Rabaté, ed. Paris: PUF, 1996. 65-79

Santí, Enrico Mario. Pablo Neruda: The Poetics of Prophecy. Ithaca, NY: Cornell UP, 1982.

Stierle, Karlheinz. "Identité du discours et transgression lyrique". Poétique 32 (1977): 422-441.

Williams, Raymond . Keywords: A Vocabulary of Culture and Society. New York: Oxford UP, 1985.

Yamal, Ricardo. "La generación de la diáspora: Oscar Hahn o la transvaluación verbal: desde la visión apocalíptica hasta el discurso esquizoide". Taller de letras 22 (1994): 23-40.

Žižek, Slavoj. Violence. New York: Picador, 2008. 